\title{
A wolf in sheep's clothing
}

\author{
President Bush's candidate is the wrong choice for the World Bank
}

$\mathrm{R}$ ock star Bono was a possibility. Actress Angelina Jolie was a wild card. Former United States Secretary of State Colin Powell was an intriguing candidate. But Paul Wolfowitz, architect of the war on Iraq, to head the World Bank? No chance. Yet that's exactly what President Bush has done.

Wolfowitz's reputation as the chief mover for the war on Iraq - a development disaster-sits uncomfortably with a job whose main role is multilateral international development and not unilateral preaching of freedom and democracy, although these bedfellows may themselves be beneficial for health. ${ }^{1}$ As a public relations exercise his appointment is a snub to the international development community, which spends much of its time carefully navigating political and cultural minefields. Many countries that Wolfowitz will be required to help are critical of America's war on Iraq and its motives. But is this to misjudge Wolfowitz? Does he fit in with the World Bank in a way that is not immediately obvious?

Wolfowitz, a mathematician turned politician, is a past dean of the School of Advanced International Studies at Johns Hopkins University-his main claim to interest in international development-and a former US ambassador to Indonesia, where he became involved in aid work. Unlike James Wolfensohn, the current World Bank president and an investment banker, Wolfowitz does not have a background in finance. His manner is described as softly spoken, engaging, and even disarming, exuding a "tortured intellectual sincerity." These characteristics contrast with his reputation as the leading neoconservative hawk in George Bush's regime.

Sensing that his reputation precedes him, Wolfowitz has begun by saying that his focus will be on economics, not politics. Perfecting his message will be an important challenge for Wolfowitz. Indeed, Wolfensohn has been a master at winning over stakeholders, particularly non-governmental organisations, and emphasising the social aspects of development, although he is criticised for failing to turn rhetoric into reality. ${ }^{3}$ This failing creates an opportunity for Wolfowitz to be effective where Wolfensohn wasn't. But Wolfowitz must achieve effectiveness through sound, evidence informed, policy making-not brazen ideology.

Richard Clarke, counterterrorism tsar for two presidents, Clinton and Bush Jnr, offers an interesting insight. ${ }^{4}$ He describes Wolfowitz's utter conviction that Iraq was responsible for the World Trade Center atrocity, a conviction that flew in the face of the evidence. None the less, Wolfowitz's view remained highly, influential in the government's decision making. This style of policy making-conviction-rich but evidencefree-will win few friends in the international development arena and risks reversing the image change that Wolfensohn has engineered for the World Bank. Robert McNamara, Wolfensohn's predecessor and US defence secretary during the Vietnam war (a sobering parallel with Wolfowitz) had made the bank deeply unpopular. Wolfensohn, who was appointed by President Clinton in 1995, proclaimed his desire to eradicate poverty and eschew profit early in his tenure and succeeded in turning his organisation into a listening bank, if not a highly effective one. ${ }^{5}$

None of this, though, managed to persuade the US administration to reappoint Wolfensohn. As a relic of the Bretton Woods agreement that created the World Bank and International Monetary Fund, the United States nominates the head of the bank and Europe nominates the head of the fund. These nominations are usually approved unchallenged by an executive board, which is comparable to the security council of the United Nations. Unusually, the United States vetoed Caio Koch-Weser, Europe's nominated head of the IMF in 2000. Other UN organisations have similar arrangements for top appointments: the head of Unicef, for example, is another selection made by the United States. This year's appointment of Ann Veneman, a former US agriculture secretary, has been criticised by public health advocates. ${ }^{6}$ These appointments systems that appease major powers and buy their participation should have no place in modern international organisations.

In the end, the Wolfowitz situation boils down to how the United States wants to be perceived by the world. His nomination, and that of John Bolton as US ambassador to the United Nations, has done little more than reinforce concerns that the current US administration is hell bent on disseminating its political ideology through control of international and non-governmental organisations. This is an abuse of power. Wolfowitz has some merits, but not enough to justify his appointment. He may well be skilled at managing a large organisation, but his is an inflammatory nomination to head the world's most influential multilateral development organisation, a post that requires acute political sensitivity and cultural awareness. His is a nomination that the World Bank's executive board would do well to reject.

\section{Kamran Abbasi deputy editor, BMJ}

Competing interests: None declared.

Franco A, Alvarez-Dardet C, Ruiz M. Effect of democracy on health: ecological study. BMJ 2004;329:1421-3.

2 Paul Wolfowitz: Hawk with a lot of loot needs a bit of lady luck. Sunday Times 2005 March 20. www.timesonline.co.uk/article/0,20881533085,00.html (accessed 24 Mar 2005).

3 Stocking B. The world's banker: a story of failed states, financial crises, and the wealth and poverty of nations. BMJ 2005;330:736.

Clarke RA. Against all enemies: inside America's war on terror. Sydney: Simon Clarke RA. Against all

Abbasi K. The World Bank and world health: changing sides. BMJ 1999;318:1003-6.

6 People's Health Movement. PHM launches the Save UNICEF Campaign to protest the appointment of Ms Ann Veneman as the next UNICEF executive director. www.phmovement.org/newsroom/index.html\#Save \%20UNICEF (accessed 24 Mar 2005). 